\title{
Znaczenie małych i średnich przedsiębiorstw w Polsce po 2000 r.
}

Małe i średnie przedsiębiorstwa (MSP) stanowią fundament gospodarki krajów Unii Europejskiej. Oddziałują nie tylko na wielkość i strukturę produkcji oraz PKB; przyczyniają się również do powstawania nowych miejsc pracy, a zatem do wzrostu zatrudnienia i zmniejszenia bezrobocia. Ponadto, dzięki dużej liczbie małych i średnich przedsiębiorstw opartych na prywatnej własności, jest zapewniona autentyczna konkurencja pomiędzy podmiotami oraz duża elastyczność w zakresie ich dostosowywania do zmieniających się warunków rynkowych. Pracownicy MSP, często będący ich właścicielami lub współwłaścicielami, mają szczególne motywacje i determinację w zakresie wysokiej efektywności działalności.

Artykuł jest próbą znalezienia odpowiedzi na następujące pytania:

- Co rozumie się pod pojęciem sektora MSP? Według jakich kryteriów zostaje on wyodrębniony?

- Jakim przeobrażeniom podlega sektor MSP w Polsce po 2000 r.?

- Jakie są stan i struktura MSP w Polsce?

- Jakie jest znaczenie sektora MSP w Polsce na tle wybranych krajów Unii Europejskiej?

- Jakie są główne dylematy rozwoju przedsiębiorczości w Polsce?

\section{Definicja i istota małych i średnich przedsiębiorstw}

Sektor małych i średnich przedsiębiorstw odgrywa ogromną rolę w krajach Unii Europejskiej. Dostępne dane z różnych źródeł o jego roli w gospodarkach Unii Europejskiej nieco się różnią. Wskazują one, że MSP to około 99,8\% wszystkich firm działających na jej obszarze, ich udział w obrotach wewnattrzunijnych przekracza 65\%, a w zatrudnieniu wynosi 69,7\% (Misiąg 2005, s. 30 i 31). Sektor wytwarza średnio niemal 60\% PKB Unii Europejskiej. Ze względu na wysoki udział w strukturze podmiotowej rynku UE silnie wpływa on na podstawowe wskaźniki ekonomiczne krajów: średni obrót, średni poziom zatrudnienia, wartość dodaną i przyrost nowych miejsc pracy; jego dynamika i kondycja stanowią więc świadectwo rozwijającej się przedsiębiorczości w każdej gospodarce.

W ostatnich latach definicja małych i średnich przedsiębiorstw zmieniała się; poszczególne kraje stosowały różne kryteria, uwzględniając przy ich wyodrębnianiu w mniejszym lub większym stopniu czynniki ilościowe i jakościowe - w zależności od celów, którym klasyfikacja miała służyć. Jednakże czynniki ilościowe powodują przemiany o charakterze jakościowym przedsiębiorstwa. Najczęściej jako kryterium ilościowe od strony nakładów stosuje się wielkość zatrudnienia, kapitału i aktywów w przedsiębiorstwie, a od strony efektów - obrót, wartość dodaną i udział w rynku. Jako kryteria jakościowe klasyfikacji firm, będące konsekwencją zmian o charakterze ilościowym, stosuje się: niezależność, własność, organizację i zarządzanie oraz szereg innych (Dominiak 2005, s. 27 i 28). Problem polega na tym, że żadna definicja nie uwzględnia wszystkich kryteriów ilościowych i jakościowych wyodrębniania MSP. 
W krajach Unii Europejskiej stosuje się trzy definicje MSP:

1. do celów statystycznych, sprawozdawczości dotyczącej MSP - akcentuje się niemal wyłącznie kryteria ilościowe, przede wszystkim wielkość zatrudnienia;

2. w rachunkowości sprawozdawczej, koncentrującej się na sumie bilansowej - istotna jest wielkość przychodów i wielkość zatrudnienia;

3. do przydziału środków pomocowych - uwzględniającą: wielkość obrotów, sumę bilansową, wielkość zatrudnienia i niezależność przedsiębiorstwa.

Unia Europejska wypracowała własną definicję małego i średniego przedsiębiorstwa. Dla krajów członkowskich nie ma ona charakteru obligatoryjnego; są one zachęcane do jej stosowania. Jest ona zawarta w zaleceniu Komisji Europejskiej 96/280/WE z 1996 r., zastappionym zaleceniem Komisji Europejskiej zmodyfikowanym w 2005 r. Zachowuje ono wszystkie dotychczasowe kryteria klasyfikacji MSP będące wynikiem ustaleń KE w 1996 r., aktualizuje poziom przychodów w odniesieniu do mikroprzedsiębiorstw oraz małych i średnich przedsiębiorstw i wprowadza łagodniejsze kryterium niezależności (Misiag 2005, s. 18 i 19).

Według kryteriów Unii Europejskiej mikroprzedsiębiorstwo zatrudnia mniej niż 10 pracowników, ma roczny obrót poniżej $2 \mathrm{mln}$ euro, a jego całkowity bilans roczny nie przekracza $2 \mathrm{mln}$ euro. Małe przedsiębiorstwo zatrudnia nie więcej niż 50 osób, jego roczny obrót to mniej niż $10 \mathrm{mln}$ euro, a całkowity bilans roczny nie przekracza $10 \mathrm{mln}$ euro. Średnia firma zatrudnia nie więcej niż 250 pracowników, jej roczny obrót nie przekracza $50 \mathrm{mln}$ euro, a bilans roczny $-43 \mathrm{mln}$ euro. W sektorze MSP obowiązuje zasada niezależności, oznaczająca, że nie uważa się za MSP firmy, w której przedsiębiorcy inni niż mali lub średni posiadają więcej niż 25\% wkładów, udziałów, akcji oraz prawa do ponad 25\% udziałów w zyskach. Progi te mogą zostać przekroczone w dwóch przypadkach, jeżeli: a) przedsiębiorstwo jest zarządzane przez spółki inwestycyjne, fundusz venture capital lub inwestorów instytucjonalnych, o ile one ani osobno, ani łącznie nie sprawują kontroli nad MSP; b) kapitał jest tak rozdzielony, że nie jest możliwe ustalenie, w czyim jest posiadaniu, a przedsiębiorstwo deklaruje, że może prawnie dowieść, że nie stanowi więcej niż 25\% własności jednego przedsiębiorstwa lub grupy przedsiębiorstw niespełniających kryterium definicji $\mathrm{MSP}^{1}$ (tab. 1).

Tab. 1. Definicja mikroprzedsiębiorstw oraz przedsiębiorstw małych i średnich w Unii Europejskiej

\begin{tabular}{|l|l|l|l|}
\hline \multicolumn{1}{|c|}{ Wyszczególnienie } & Mikroprzedsiębiorstwo & \multicolumn{1}{|c|}{$\begin{array}{c}\text { Przedsiębiorstwo } \\
\text { male }\end{array}$} & \multicolumn{1}{|c|}{$\begin{array}{c}\text { Przedsiębiorstwo } \\
\text { średnie }\end{array}$} \\
\hline Zatrudnienie & $\begin{array}{l}\text { poniżej } 10 \\
\text { pracowników }\end{array}$ & $\begin{array}{l}\text { poniżej } 50 \\
\text { pracowników }\end{array}$ & $\begin{array}{l}\text { od 50 do } 249 \\
\text { pracowników }\end{array}$ \\
\hline $\begin{array}{l}\text { Przychód } \\
\text { ze sprzedaży }\end{array}$ & do 2 mln euro & do 10 mln euro & do 50 mln euro \\
\hline $\begin{array}{l}\text { Suma bilansów } \\
\text { z aktywów }\end{array}$ & do 2 mln euro & do10 mln euro & do 43 mln euro \\
\hline Zależność & niezależne & niezależne & niezależne \\
\hline
\end{tabular}

Źródło: http:// www.parp.gov.pl/kwalifikator/index.html oraz załącznik do Rozporządzenia Komisji Europejskiej nr 346/2004, zmieniającego i rozszerzającego zakres Rozporządzenia Komisji Europejskiej nr 70/2001.

\footnotetext{
${ }^{1}$ Załącznik do Rozporządzenia Komisji Europejskiej nr 346/2004, zmieniającego i rozszerzającego zakres Rozporządzenia Komisji Europejskiej nr 70/2001.
} 
Unijna definicja małego i średniego przedsiębiorstwa została przejęta do polskiej ustawy Prawo działalności gospodarczej. Wobec krajowych MSP ustanawia ona takie same kryteria, jakie obowiązują w Unii Europejskiej. Wyrazem dbałości o rozwój przedsiębiorczości na obszarze Unii Europejskiej jest fakt, że unijne prawo dopuszcza działalność spółek w formach paneuropejskich, do których są zaliczane:

- spółka europejska,

- europejskie zgrupowanie interesów gospodarczych,

- spółdzielnia europejska,

- europejska spółka prywatna,

- europejska spółka wzajemna,

- stowarzyszenie europejskie.

Szczególne znaczenie wśród tych form ma europejska spółka akcyjna. Warunkiem jej powstania są:

- konsolidacja co najmniej dwóch spółek pochodzących z co najmniej dwóch krajów;

- połączenie spółki z jej oddziałem lub spółką zależną z innego państwa Unii Europejskiej;

- przekształcenie istniejącej spółki akcyjnej, która ma własny oddział w innym kraju UE od co najmniej dwóch lat.

Zaletą spółki europejskiej jest możliwość pomijania barier biurokratycznych, gdyż może ona działać we wszystkich krajach członkowskich, bez konieczności rejestrowania jej w każdym kraju.

\section{Znaczenie MSP w Unii Europejskiej}

Małe i średnie przedsiębiorstwa odgrywają w Unii Europejskiej ogromną rolę. Wynika ona $\mathrm{z}$ określonych cech tych przedsiębiorstw; są to:

- wysoki poziom elastyczności w dostosowywaniu zmian w otoczeniu firmy do zmian w popycie zgłaszanym przez klienta;

- wysoki poziom motywacji przedsiębiorcy, wynikający ze ścisłego związku między rentownością firmy a dochodami jej właściciela;

- szczególna rola właściciela, która sytuuje go w strukturze przedsiębiorstwa jako menedżera. Jest on w stanie zrealizować każdy zamiar na własne ryzyko, niepodlegające kontroli osób trzecich. Oznacza to (Mate i średnie przedsiębiorstwa... 2004, s. 14), że MSP charakteryzują się niezależnością i swobodą decyzyjną;

- możliwość podejmowania szybkich decyzji, wynikająca z braku biurokracji, szybkiego przepływu informacji, częstych kontaktów właściciela z pracownikami;

- wysoka efektywność działania, powiązana z dużą dyscypliną finansową;

- niska kapitałochłonność produkcji, umożliwiająca oszczędności w nakładach;

- duża skłonność innowacyjna, podnosząca poziom innowacyjności krajów UE (Żołnierski 2006);

- wysoki udział w kreacji nowych miejsc pracy oraz elastyczność polityki zatrudnienia;

- silny wpływ na rozwój lokalny, lokalną przedsiębiorczość.

Wszystkie wymienione cechy sektora MSP powodują że w krajach UE ma on wysoki udział w całkowitej liczbie funkcjonujących firm, w wielkości obrotów, zatrudnieniu, wartości dodanej oraz eksporcie (tab. 2).

\footnotetext{
${ }^{2}$ Decyzja Rady WE 21/57 z października 2001 r. dotycząca nowej spółki akcyjnej, określanej mianem spółki europejskiej.
} 
Tab. 2. Sektor MSP w Unii Europejskiej w 2003 r. ${ }^{3}$

\begin{tabular}{|c|c|c|c|c|}
\hline Wyszczególnienie & Rok & Mikroprzedsiębiorstwa & $\begin{array}{c}\text { Przedsiębiorstwa } \\
\text { małe }\end{array}$ & $\begin{array}{c}\text { Przedsiębiorstwa } \\
\text { średnie }\end{array}$ \\
\hline $\begin{array}{l}\text { Liczba } \\
\text { przedsiębiorstw } \\
\text { (w tys.) }\end{array}$ & 2003 & 17820 & 1260 & 180 \\
\hline $\begin{array}{l}\text { Zatrudnienie } \\
\text { ogółem (w tys.) }\end{array}$ & 2003 & 55040 & 24280 & 18100 \\
\hline $\begin{array}{l}\text { Przeciętne } \\
\text { zatrudnienie } \\
\text { w przedsiębiorstwie }\end{array}$ & 2003 & 3 & 19 & 98 \\
\hline $\begin{array}{l}\text { Średni obrót } \\
\text { (w mln euro) }\end{array}$ & 2000 & 0,2 & 3 & 24 \\
\hline $\begin{array}{l}\text { Wartość dodana } \\
\text { na } 1 \text { zatrudnionego } \\
\text { (w mln euro) }\end{array}$ & 2000 & 40 & 75 & 105 \\
\hline $\begin{array}{l}\text { Udział kosztów } \\
\text { pracy w wartości } \\
\text { dodanej }(\mathrm{w} \%)\end{array}$ & 2000 & 66 & 66 & 8 \\
\hline $\begin{array}{l}\text { Udział eksportu } \\
\text { w sprzedaży } \\
\text { ogółem (w \%) }\end{array}$ & 2000 & 7 & 14 & 17 \\
\hline
\end{tabular}

Źródło: opracowanie autora na podstawie: Pomoc publiczna, F. Misiąg (red.), s. 31; Przede wszystkim MSP. Europa jest dobra dla MSP a MSP są dobre dla Europy, Komisja Europejska DG ds. Przedsiębiorstw i Przemysłu 2006.

Z tabeli wynika, że w 2003 r. na obszarze UE i krajów EFTA funkcjonowało 19260 MSP zatrudniających $97 \mathrm{mln} 420$ tys. pracowników. Stanowiło to 92,3\% całkowitej liczby przedsiębiorstw zatrudniających 56,5\% ogółu zatrudnionych. Średnia wartość obrotów przekroczyła 9 mln euro, a wartość dodana na 1 zatrudnionego przekroczyła 73 tys. euro. W 2006 r. w 23 mln europejskich MSP (Przede wszystkim MSP... 2006) było $100 \mathrm{mln}$ miejsc pracy i ponad 75\% zatrudnienia w niektórych gałęziach przemysłu (jak: przemysł tekstylny, budowlany i meblarski).

Pod względem wielkości w strukturze firm w krajach Unii Europejskiej przeważały mikroprzedsiębiorstwa (tab. 3).

W strukturze sektora MSP 15 krajów Unii Europejskiej przeważają mikroprzedsiębiorstwa. Stanowią one ponad 92\% wszystkich przedsiębiorstw, a największy udział (powyżej 95\%) mają w Grecji i we Włoszech. Przedsiębiorstwa małe to ponad 6\% wszystkich przedsiębiorstw w Unii Europejskiej. Podobnie jak w przypadku mikroprzedsiębiorstw, ich udział w krajach UE jest zróżnicowany. Największy relatywnie odsetek (powyżej 11\%) stanowią w Austrii, Irlandii i Luksemburgu. Przedsiębiorstwa średnie w strukturze MSP mają najmniejszy udział, wynoszący około 1\%, a w niektórych krajach (jak Luksemburg czy Irlandia) 2\% i więcej.

\footnotetext{
${ }^{3}$ Dane te ujmują sektor MSP łącznie: w Unii Europejskiej i w krajach EFTA.
} 
Tab. 3. Struktura MSP w 15 krajach Unii Europejskiej

\begin{tabular}{|c|c|c|c|c|c|c|c|}
\hline \multirow[t]{2}{*}{ Kraje } & \multicolumn{2}{|c|}{$\begin{array}{c}\text { Mikro- } \\
\text { przedsiębiorstwa }\end{array}$} & \multicolumn{2}{|c|}{$\begin{array}{c}\text { Przedsiębiorstwa } \\
\text { małe }\end{array}$} & \multicolumn{2}{|c|}{$\begin{array}{c}\text { Przedsiębiorstwa } \\
\text { średnie }\end{array}$} & \multirow{2}{*}{$\begin{array}{c}\text { Ogółem } \\
\text { MSP } \\
\text { (w tys.) }\end{array}$} \\
\hline & w tys. & w\% & w tys. & $\mathbf{w \%}$ & w tys. & $w \%$ & \\
\hline Austria & 233 & 86,9 & 30 & 11,2 & 5 & 1,9 & 268 \\
\hline Belgia & 408 & 93,4 & 25 & 5,7 & 4 & 0,9 & 437 \\
\hline Dania & 180 & 87,8 & 21 & 10,2 & 4 & 2,0 & 205 \\
\hline Finlandia & 207 & 93,7 & 12 & 5,4 & 2 & 0,9 & 221 \\
\hline Francja & 2326 & 93,2 & 144 & 5,8 & 25 & 1,0 & 2495 \\
\hline Grecja & 752 & 97,7 & 16 & 2,1 & 2 & 0,2 & 770 \\
\hline Hiszpania & 2499 & 93,5 & 156 & 5,8 & 19 & 0,7 & 2674 \\
\hline Holandia & 517 & 90,9 & 43 & 7,6 & 9 & 1,5 & 569 \\
\hline Irlandia & 83 & 85,6 & 12 & 12,4 & 2 & 2,0 & 97 \\
\hline Luksemburg & 21 & 84,0 & 3 & 12,0 & 1 & 4,0 & 24 \\
\hline Niemcy & 2656 & 88,3 & 307 & 10,2 & 44 & 1,5 & 3007 \\
\hline Portugalia & 648 & 93,5 & 39 & 5,6 & 6 & 0,9 & 693 \\
\hline Szwecja & 454 & 93,6 & 27 & 5,6 & 4 & 0,8 & 485 \\
\hline Wielka Brytania & 1996 & 89,6 & 200 & 9,0 & 31 & 1,4 & 2227 \\
\hline Włochy & 4290 & 95,7 & 177 & 3,9 & 19 & 0,4 & 4486 \\
\hline Unia Europejska & 17272 & 92,6 & 1212 & 6,5 & 177 & 0,9 & 18659 \\
\hline
\end{tabular}

Źródło: opracowanie autorki na podstawie: Pomoc publiczna, F. Misiąg (red.), s. 31; Przede wszystkim MSP. Europa jest dobra dla MSP a MSP są dobre dla Europy, Komisja Europejska DG ds. Przedsiębiorstw i Przemysłu 2006.

Reasumując: struktura sektora MSP w 15 krajach UE jest zróżnicowana. Prezentowane współczynniki dotyczące struktury MSP wykazałyby jeszcze większe zróżnicowanie, gdyby do „starej” UE dołączono nowe kraje, przechodzące proces transformacji od gospodarki centralnej do gospodarki rynkowej.

\section{Małe i średnie przedsiębiorstwa w Polsce}

W Polsce również dostrzeżono rolę małych i średnich przedsiębiorstw w gospodarce narodowej. Obecnie Polska, jako członek Unii Europejskiej, a także wcześniej - na etapie stowarzyszenia, starała się i stara zwiększyć efektywność i konkurencyjność sektora MSP. Podjęto działania mające na celu wspieranie MSP i usuwanie barier na drodze ich powstawania i rozwoju. Efektem tych działań był dynamiczny wzrost MSP w Polsce w latach 1994-1999, z 1106 do ponad 1819, czyli o ponad $60 \%$, związany z urynkowieniem gospodarki oraz z prywatyzacją przedsiębiorstw państwowych. W 2004 r. sektor MSP stanowił 99,8\% ogółu funkcjonujących w Polsce przedsiębiorstw (duże przedsiębiorstwa - tylko 0,15\%) (Kwiatkowska 2006 ) (tab. 4).

W 2004 r. powstało mniej nowych firm niż w 2003 r.; w tym samym roku więcej firm zlikwidowano niż w 2003 r. Wyjątek stanowiły firmy małe i średnie, charakteryzujące się większą odpornością na zmiany koniunktury. 
Tab. 4. Liczba aktywnych przedsiębiorstw w Polsce w latach 1999-2004 (w tys.)

\begin{tabular}{|c|c|c|c|c|c|c|c|c|c|c|c|c|}
\hline \multirow[t]{2}{*}{ Przedsiębiorstwa } & \multicolumn{2}{|c|}{1999} & \multicolumn{2}{|c|}{2000} & \multicolumn{2}{|c|}{2001} & \multicolumn{2}{|c|}{2002} & \multicolumn{2}{|c|}{2003} & \multicolumn{2}{|c|}{2004} \\
\hline & w tys. & w\% & w tys. & w\% & w tys. & w \% & w tys. & $\mathbf{w} \%$ & w tys. & w\% & w tys. & $\mathbf{w} \%$ \\
\hline Mikroprzedsiębiorstwa & 1760,6 & 96,78 & 1709,8 & 96,81 & 1602,0 & 96,64 & 1682,5 & 96,65 & 1654,1 & 96,76 & 1640,9 & 97,08 \\
\hline Małe & 41,1 & 2,26 & 39,0 & 2,21 & 39,4 & 2,38 & 37,1 & 2,14 & 39,5 & 2,31 & 34,9 & 2,06 \\
\hline Średnie & 14,3 & 0,78 & 14,2 & 0.81 & 13,4 & 0,81 & 13,1 & 0,75 & 13,3 & 0,78 & 12,0 & 0,71 \\
\hline Duże & 3,2 & 0,18 & 3,1 & 0,17 & 2,8 & 0,17 & 2,7 & 0,16 & 2,6 & 0,16 & 2,6 & 0,15 \\
\hline Ogółem & 1819,2 & 100,0 & 1766,1 & 100,0 & 1657,6 & 100 & 1735,4 & 100,0 & 1709,5 & 100,0 & 1690,4 & 100,0 \\
\hline $\begin{array}{l}\text { Aktywne } \\
\text { jako \% zarejestrowanych }\end{array}$ & & 64,18 & & 59,44 & & 53,11 & & 53,46 & & 51,09 & & 50,41 \\
\hline
\end{tabular}

Źródło: obliczenia na podstawie danych GUS i J. Chmiel (red), Stan sektora MSP w 2003 roku. Tendencje rozwojowe w latach 1994-2005, MGiP PARP, Warszawa 2005.

Według GUS, w 2004 r., podobnie jak w latach poprzednich, przeważającą grupę nowych firm stanowiły zakłady osób fizycznych prowadzących działalność gospodarczą. Najczęściej powstawały one nie w wyniku przekształceń firm istniejących, ale jako podmioty nowe (93,1\% wszystkich nowo powstałych firm w 2004 r., tyle samo co w roku poprzednim). Zdecydowanie częściej powstawały firmy, w których nie zatrudniano pracowników najemnych. Struktura branżowa nowo powstałych przedsiębiorstw była względnie stabilna (ryc. 1). W 2004 r. przedsiębiorstwa handlowe stanowiły $44,1 \%$ wszystkich nowo tworzonych firm. Na drugim miejscu były przedsiębiorstwa zaliczane do sekcji obsługa nieruchomości i firm (21,4\%)(Raport o stanie sektora małych $i$ średnich przedsiębiorstw w Polsce 2007). Kolejną grupę - 10-11\% - stanowiły przedsiębiorstwa przemysłowe, $7-8 \%$ - firmy transportowe, $9-11 \%$ - budowlane, a 5\% - firmy z sekcji hotele i restauracje.

Ryc. 1. Struktura nowo powstałych przedsiębiorstw według sekcji gospodarki w latach 2001-2004 (w \%)

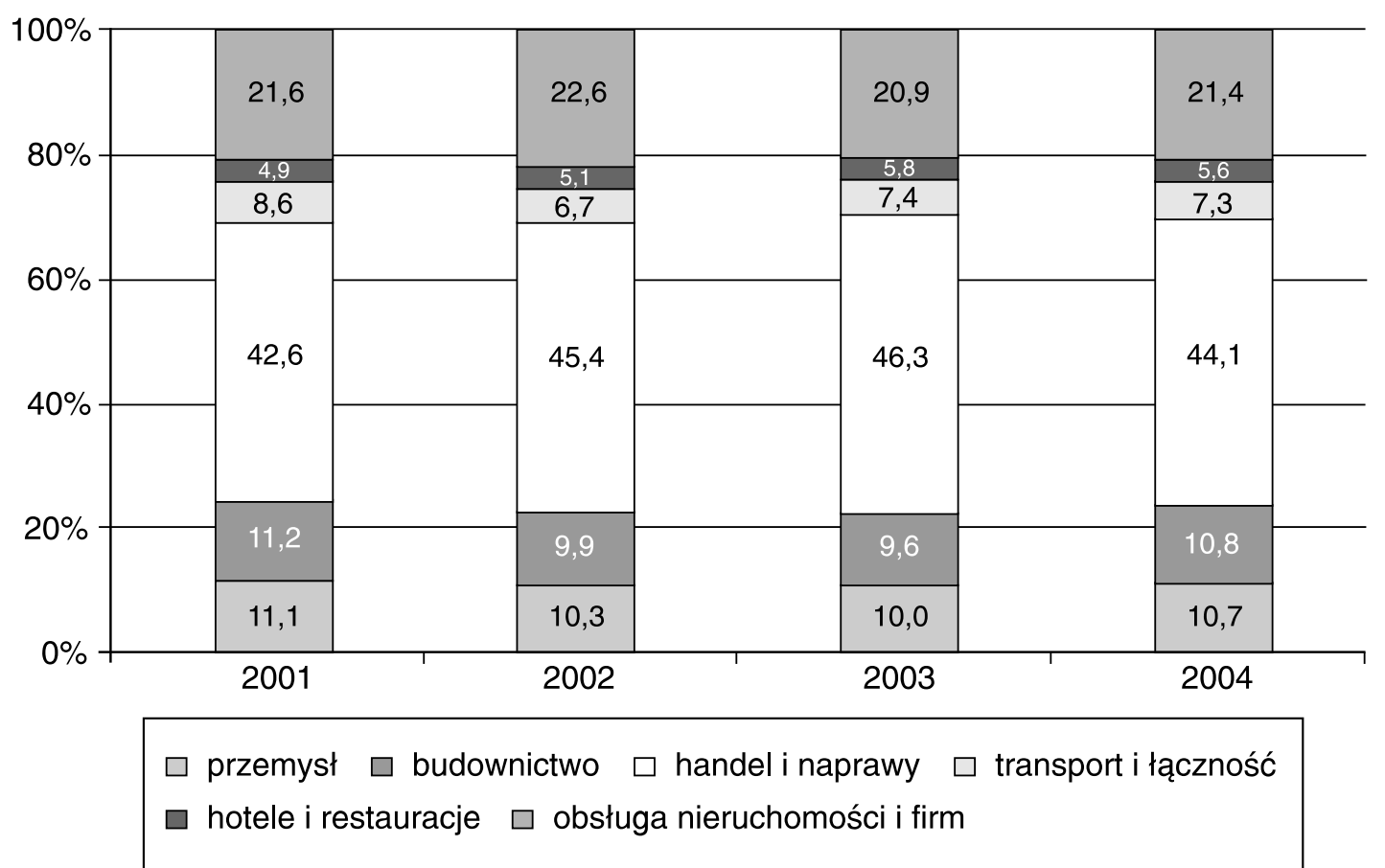

Źródło: Raport o stanie sektora małych i średnich przedsiębiorstw w Polsce, Polska Agencja Przedsiębiorczości, Warszawa 2007. 
Na podkreślenie zasługuje fakt, że nowe firmy nie były tworzone równomiernie w całym kraju. W 2004 r. aż 28,3\% przedsiębiorstw powstało w dwóch województwach: mazowieckim i śląskim. $\mathrm{Na}$ drugim biegunie znalazły się województwa ściany wschodniej. W pięciu województwach: warmińsko-mazurskim, podlaskim, lubelskim, świętokrzyskim i podkarpackim powstała jedynie co szósta nowo utworzona firma. Co więcej, z roku na rok odnotowuje się pogłębianie tej tendencji.

\section{Przedsiębiorczość w Polsce w latach 2004-2006}

Rok 2005 i kolejne lata odwróciły tę tendencję na korzyść nowo rejestrowanych podmiotów. Liczba podmiotów zarejestrowanych $w$ rejestrze REGON ${ }^{4}$ (z pominięciem rolnictwa i leśnictwa, rybołówstwa i rybactwa oraz administracji publicznej) w końcu 2004 r. wyniosła 3465 793, w rok później 3501 114, a na koniec 2006 r. - 3517898 (tab. 5).

Tab. 5. Podmioty gospodarcze zarejestrowane w rejestrze REGON (z pominięciem rolnictwa i leśnictwa, rybołówstwa i rybactwa oraz administracji publicznej)

Stan w końcu roku

\begin{tabular}{|c|c|c|c|c|c|}
\hline \multirow[t]{2}{*}{ Rok } & \multirow[t]{2}{*}{ Ogółem } & \multicolumn{4}{|c|}{$\begin{array}{l}\text { W tym podmioty o liczbie zatrudnionych } \\
\text { (liczba podmiotów według stanu na koniec roku) }\end{array}$} \\
\hline & & 0-9 & $10-49$ & $50-249$ & powyżej 249 \\
\hline 2004 & 3465793 & 3302511 & 134031 & 24907 & 4344 \\
\hline 2005 & 3501114 & 3333607 & 138321 & 25017 & 4169 \\
\hline \multirow[t]{2}{*}{2006} & 3517898 & 3348708 & 139986 & 25057 & 4147 \\
\hline & \multicolumn{5}{|c|}{ Rok poprzedni $=100$} \\
\hline 2004 & 100,3 & 100,2 & 103,0 & 100,3 & 96,0 \\
\hline 2005 & 101,0 & 100,9 & 103,2 & 100,4 & 96,0 \\
\hline 2006 & 100,5 & 100,5 & 101,2 & 100,2 & 99,5 \\
\hline
\end{tabular}

Źródło: Raport o stanie sektora małych i średnich przedsiębiorstw w Polsce, Polska Agencja Rozwoju Przedsiębiorczości, Warszawa 2007.

Najszybciej rosła liczba zarejestrowanych podmiotów o zatrudnieniu od 10 do 49 osób, a zmalała liczba podmiotów zatrudniających więcej niż 249 osób.

W latach 2004-2006 liczba podmiotów wyrejestrowanych z REGON-u, w odróżnieniu od liczby podmiotów zarejestrowanych ogółem, rosła bardzo szybko. W roku 2004 wyniosła ona 191257 (wzrosła o 37,5\% w porównaniu z rokiem poprzednim), w rok później-211 042 (wzrost o 10,3\%), a w 2006 r. - 267467 (wzrost o 26,7\%). Nie należy jednak wyciagać z tego daleko idących wniosków dotyczących wyłącznie koniunktury gospodarczej we wspomnianym okresie, ponieważ w poszczególnych latach wykreślane były z REGON-u także te podmioty, które zakończyły działalność dużo wcześniej.

\footnotetext{
${ }^{4} \mathrm{~W}$ niniejszym opracowaniu podano liczby podmiotów zarejestrowanych, nowo zarejestrowanych i wykreślonych z rejestru REGON, z pominięciem tzw. jednostek lokalnych. Informacje na ten temat podaje GUS w corocznych publikacjach pt.: Zmiany strukturalne grup podmiotów gospodarki narodowej.
} 
W latach 2004-2006 liczba nowo zarejestrowanych podmiotów ${ }^{5}$ rosła. W 2004 r. wynosiła 227 729, w 2005 r. wzrosła do 255 624, a w roku 2006 - aż do $291201^{6}$. Szybkie tempo wzrostu liczby rejestrowanych nowych podmiotów w latach 2005 i 2006, po kilku latach spadku, mogłoby więc świadczyć o poprawie koniunktury gospodarczej również na produkty i usługi małych przedsiębiorstw, którymi są - z niewielkimi wyjątkami - firmy prowadzone przez osoby fizyczne. Jednak w naszych szczególnych warunkach funkcjonowania małych firm tendencję wzrostu liczby nowo zarejestrowanych podmiotów trzeba interpretować ostrożnie. Istnieją uzasadnione obawy, że związane to było z masowym przechodzeniem pracowników firm prywatnych na tzw. samozatrudnienie ${ }^{7}$. Pracownicy przedsiębiorstw tworzyli jednoosobowe firmy, przy czym wykonywali na rzecz poprzednich pracodawców te same czynności, które wykonywali wcześniej na etatach, co umożliwiło ich dotychczasowym pracodawcom znaczną redukcję kosztów, m.in. w wyniku zmniejszenia wysokości składek na ubezpieczenie społeczne. Charakterystyczne, że sekcją, w której liczba nowo zarejestrowanych podmiotów osób fizycznych w latach 2005 i 2006 wzrosła najszybciej (ponaddwukrotnie), było budownictwo, bo właśnie w budownictwie organizacja pracy poprzez wynajmowanie podwykonawców (np.: murarzy, zbrojarzy czy tynkarzy pracujących jako jednoosobowe firmy) była szczególnie łatwa i przynosiła największe oszczędności.

Mimo szybkiego wzrostu liczby firm nowo zarejestrowanych w 2005 r., liczba przedsiębiorstw aktywnych ${ }^{8}$ malała zarówno w 2004 r., jak i 2005 r. W 2004 r. wynosiła 1704 527, czyli o 0,5\% mniej niż rok wcześniej, a w 2005 r. spadła do 1666 679, a więc aż o 2,2\%. Spadek w 2005 r. był skutkiem zmniejszenia się liczby mikroprzedsiębiorstw zatrudniających do 9 osób - o 2,3\%, czyli o ponad 38 tys. jednostek. Najszybszy spadek liczby mikroprzedsiębiorstw zaobserwowano w 2005 r. w sekcjach: przetwórstwo przemysłowe (o 8,5\%), transport, gospodarka magazynowa i łączność (o 4,5\%), obsługa nieruchomości i firm (o 3,5\%) oraz handel i naprawy (o 3,3\%).

Jeśli przyjmiemy za 100\% ogólną liczbę wszystkich aktywnych MSP w 2005 r. (ryc. 2.), to najwięcej z nich działało w sekcji handel i naprawy $(35,4 \%)$, w obsłudze nieruchomości i firm $(16 \%)$, w przemyśle $(11,6 \%)$, budownictwie $(9,6 \%)$ oraz transporcie, gospodarce magazynowej i łączności (8,2\%). Na szóste miejsce pod względem wysokości udziału firm małych i średnich w ogólnej liczbie aktywnych MSP (6,4\%) wysunęła się ochrona zdrowia, dzięki szybkiemu wzrostowi liczby prywatnych przychodni i klinik (w 2004 r. o prawie 5\%, a w 2005 r. o prawie 11\%), spowodowanemu złym funkcjonowaniem publicznej opieki zdrowotnej.

\footnotetext{
${ }^{5}$ Liczba zarejestrowanych jednostek według stanu na koniec kolejnego roku, pomniejszona o liczbę jednostek nowo powstałych i powiększona o liczbę jednostek wykreślonych z rejestru w tym roku nie musi się pokrywać z liczbą jednostek według stanu z końca roku poprzedniego. W ciagu danego roku niektóre podmioty mogły bowiem zmienić rodzaj przeważającej działalności i przemieścić się z sekcji, które nie są rozpatrywane w niniejszym opracowaniu, do innych sekcji. Inne jednostki mogły zostać na ich wniosek „ożywione”, czyli przywrócone z historycznej bazy systemu REGON (do której trafiły jako zlikwidowane) do bazy jednostek, ,żyjących”.

${ }^{6}$ Raport o stanie sektora..., op. cit.

${ }^{7} \mathrm{~W} 2007$ r. możliwości samozatrudnienia zostały ograniczone.

${ }^{8}$ Informację o liczbie przedsiębiorstw aktywnych, czyli rzeczywiście funkcjonujących w gospodarce, przedstawia GUS w corocznych publikacjach pt.: Działalność przedsiębiorstw niefinansowych.
} 
Ryc. 2. MSP w podstawowych sekcjach gospodarki poza rolnictwem w 2005 r. (w \%)

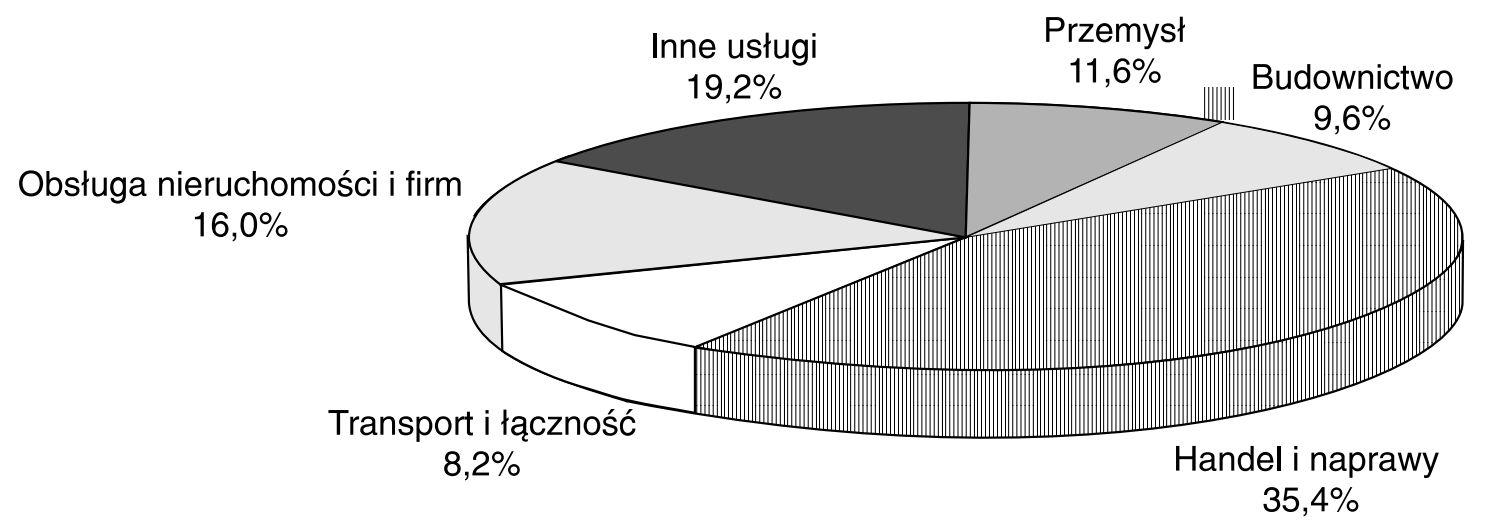

Źródło: Raport o stanie sektora małych i średnich przedsiębiorstw w Polsce, Polska Agencja Przedsiębiorczości, Warszawa 2007.

Ważne kwestie dla przedsiębiorczości w danym kraju to nie tylko liczba funkcjonujących MSP, ich aktywność, powstawanie nowych firm bądź likwidacja istniejących, ale również ich przeżywalność. Zajmuje się nią tzw. demografia przedsiębiorstw9 ${ }^{9}$ Jest to gałąź wiedzy dotycząca dynamiki powstawania nowych firm i upadku firm istniejących. Dostarcza ona wskaźników, które mogą być traktowane (oprócz dynamiki wzrostu PKB) jako barometr kondycji gospodarki kraju. Te wskaźniki odzwierciedlają nie tylko wpływ tzw. twardych czynników wzrostu gospodarczego, ale także tych niemierzalnych, związanych z nastrojami inwestorów i ich przewidywaniami dotyczącymi możliwości prowadzenia przedsiębiorstw.

\section{Przeżywalność firm powstałych w latach 2001-2005}

Badania zdecydowanie potwierdzają, że przedsiębiorstwu najtrudniej jest przetrwać pierwszy rok działalności. W tym okresie kończyło działalność średnio około 40\% firm (tab. 6).

Tab. 6. Przeżywalność przedsiębiorstw powstałych w latach 2001-2004

\begin{tabular}{|c|r|r|r|}
\hline Rok utworzenia & $\begin{array}{c}\text { Liczba przedsiębiorstw } \\
\text { zarejestrowanych }\end{array}$ & $\begin{array}{c}\text { Współczynnik } \\
\text { przeżycia } \\
\text { pierwszego roku } \\
\text { (w \%) }\end{array}$ & $\begin{array}{c}\text { Współczynnik } \\
\text { przeżycia do 2005 r. } \\
\text { (w \%) }\end{array}$ \\
\hline 2001 & 209384 & 64,5 & 31,9 \\
\hline 2002 & 176492 & 61,5 & 35,2 \\
\hline 2003 & 176867 & 64,4 & 50,4 \\
\hline 2004 & 155853 & 61,6 & 61,6 \\
\hline
\end{tabular}

Źródło: Raport o stanie sektora małych i średnich przedsiębiorstw w Polsce, Polska Agencja Rozwoju Przedsiębiorczości, Warszawa 2007.

\footnotetext{
${ }^{9}$ Na podstawie cyklicznych badań GUS, przedstawianych corocznie w publikacjach: Warunki powstania i działania oraz perspektywy rozwojowe polskich przedsiębiorstw powstatych w latach 2001-... (do roku, którego publikacja dotyczy).
} 
Należy podkreślić, że współczynnik przeżycia w pierwszym roku był zróżnicowany w poszczególnych sekcjach gospodarki (tab. 7). Najsilniej spadł w budownictwie, aż o 8,5 punktu procentowego. Przedsiębiorstwa budowlane i przedsiębiorstwa związane z turystyką najczęściej kończyły działalność w kolejnych latach. Na przykład, z firm budowlanych założonych w 2001 r. jedynie 25,3\% przeżyło do 2005 r., podczas gdy średnio dla firm wszystkich branż ten współczynnik wyniósł 31,9\%. W sekcji hotele i restauracje przeżyło jedynie $22,4 \%$ firm. Największe szanse na przeżycie pierwszego roku miały przedsiębiorstwa przemysłowe, a szanse znacznie powyżej średniej - przedsiębiorstwa transportowe oraz zaliczane do sekcji obsługa nieruchomości i firm.

Tab. 7. Współczynnik przeżycia pierwszego roku przez przedsiębiorstwa utworzone w latach 2001-2004 - według rodzaju działalności

\begin{tabular}{|l|r|r|r|r|}
\hline \multicolumn{1}{|c|}{ Sekcje gospodarki } & \multicolumn{2}{|c|}{$\mathbf{2 0 0 1}$} & \multicolumn{1}{c|}{$\mathbf{2 0 0 2}$} & \multicolumn{1}{c|}{$\mathbf{2 0 0 3}$} \\
\hline Przemysł & 65,4 & 66,2 & 70,5 & 68,9 \\
\hline Budownictwo & 61,9 & 58,5 & 67,2 & 58,7 \\
\hline Handel & 64,4 & 62,2 & 62,1 & 58,8 \\
\hline Transport & 74,6 & 66,2 & 67,4 & 65,3 \\
\hline Hotele i restauracje & 57,2 & 57,0 & 60,1 & 54,3 \\
\hline Obsługa nieruchomości i firm & 63,0 & 59,0 & 65,5 & 65,9 \\
\hline Średnio & 64,5 & 61,5 & 64,4 & 61,6 \\
\hline
\end{tabular}

Źródło: Raport o stanie sektora małych i średnich przedsiębiorstw w Polsce, Polska Agencja Rozwoju Przedsiębiorczości, Warszawa 2007.

Badania GUS wskazują różnorodne przyczyny niskiej przeżywalności przedsiębiorstw. W rok po rozpoczęciu działalności 43,8\% firm powstałych w 2004 r. nie natknęło się na żadne bariery. To o blisko 5,5 punktu procentowego więcej niż w roku poprzednim. Spośród pozostałych, $38,8 \%$ firm napotykało na trudności związane z popytem, 13,9\% - na trudności związane z popytem i z podażą, a $3,4 \%$ - jedynie na trudności z podażą ${ }^{10}$.

Spośród różnego rodzaju trudności związanych z popytem, w rok po rozpoczęciu działalności przedsiębiorstwa najczęściej wymieniały silną konkurencję. Ta bariera była najsilniej odczuwana przez firmy, bez względu na branżę, lokalizację przedsiębiorstwa czy cechy właściciela. Nieco ponad 50\% wskazań uzyskały też dwie inne bariery: obniżanie cen przez firmy konkurencyjne (także bariera związana z silną konkurencją rynkowa) oraz niewystarczające środki finansowe klientów. Dużo rzadziej wymieniano bariery podażowe: wskazywano na niedostateczne własne środki finansowe i trudności z uzyskaniem kredytu bankowego.

Od lat badania potwierdzają, że w Polsce zdecydowanie niewystarczające jest finansowanie zewnętrzne przedsiębiorstw, bez niego zaś trudno spodziewać się wzrostu inwestycji, a w konsekwencji - szybkiego i trwałego rozwoju gospodarczego. Także badania GUS pokazują że przedsiębiorcy otwierający własną firmę zdecydowanie najczęściej finansująjej działania ze środków własnych (86,5\% przedsiębiorców w 2005 r. wobec 88,9\% w 2004 r.) lub środków swoich rodzin. Z kredytu bankowego była finansowana marginalna część przedsięwzięć. Korzystało z niego jedynie 4,1\% przedsiębiorców (wobec 3,2\% w 2004 r.), a 3,6\% przedsiębiorców wykorzystało także inne źródła finansowania, m.in. środki z Unii Europejskiej (1,9\% w 2004 r.). Ta bariera finansowa od lat

${ }^{10}$ Dane GUS z 2006 r. 
ogranicza możliwości powstawania nowych firm, ale także rozwoju firm istniejących, ponieważ znacznie zmniejsza możliwości inwestowania i wdrażania nowych technologii, co jest procesem kapitałochłonnym (tab. 8).

Tab. 8. Odsetek jednostek aktywnych inwestujących - według roku utworzenia podmiotu

\begin{tabular}{|l|r|r|r|}
\hline \multirow{2}{*}{ Rok utworzenia } & \multirow{2}{*}{$\begin{array}{c}\text { Jednostki aktywne } \\
\text { inwestujące - w rok }\end{array}$} & \multicolumn{2}{|l|}{ Wspólczynnik przeżycia pierwszego roku (w \%) } \\
\cline { 3 - 4 } & po utworzeniu (w \%) & firmy inwestujące & firmy nieinwestujące \\
\hline 2001 & 24,7 & 75,8 & 55,9 \\
\hline 2002 & 27,8 & 83,2 & 68,1 \\
\hline 2003 & 27,1 & 84,2 & 75,9 \\
\hline 2004 & 28,8 & $\mathrm{x}$ & $\mathrm{x}$ \\
\hline
\end{tabular}

Źródło: Raport o stanie sektora małych i średnich przedsiębiorstw w Polsce, Polska Agencja Rozwoju Przedsiębiorczości, Warszawa 2007.

Już w latach 1995-2000 badania pokazały, że czynnikiem najsilniej wpływającym na dalsze losy przedsiębiorstwa są inwestycje nowe, modernizacyjne, o dużym technologicznym zaawansowaniu. Co roku inwestuje zaledwie 20-30\% wszystkich przedsiębiorstw (w 2004 r. - 28,8\%). Inwestowanie zwiększa współczynnik przeżycia MSP o około 10 punktów procentowych; taka tendencja jest obserwowana od pierwszych badań przeżywalności podjętych przez GUS. Mimo że związek między inwestycjami a współczynnikiem przeżycia jest niezaprzeczalny, przedsiębiorstwa zbyt rzadko korzystają z możliwości, jakie dają korzyści z inwestowania w nowe technologie. Odsetek inwestujących nie zwiększa się wraz z długością okresu istnienia firmy na rynku. W świetle badań, w kolejnych latach działalności nadal inwestuje po około 20-30\% firm. Tymczasem badania wskazują, że z roku na rok prawdopodobieństwo przeżycia firmy inwestującej wzrasta. W 2005 r. współczynnik przeżycia był różny w zależności od tego, czy firma inwestuje, o 8,3 punktu procentowego dla firm założonych w roku 2003 i aż o 20 punktów procentowych dla firm założonych w roku 2001 - w stosunku do firm niedokonujących inwestycji.

Ważnym czynnikiem determinującym okres istnienia firmy jest innowacyjność. Jest to niestety słaba strona polskiego sektora MSP; według badań Polskiej Agencji Przedsiębiorczości tylko $5 \%$ małych firm (13\% większych) prowadzi działalność badawczo-rozwojowa, ponadto zdecydowana większość spośród nich nie wydaje na ten cel więcej niż 20 tys. zł rocznie. Wynika to z wysokiego kosztu pozyskiwania kapitału i braku kapitału własnego, a także niedostrzegania przez wielu przedsiębiorców znaczenia tego czynnika rozwoju. Wydaje się ponadto, że MSP nie otrzymują należytego wsparcia od instytucji naukowo-badawczych (Bartkowiak 2005, s. 13 ).

Wpływ na przyszłe wyniki firmy, oprócz decyzji o inwestycjach, mają także inne decyzje przedsiębiorstw dotyczące sposobu ich działania. Na przykład, prawdopodobieństwo przeżycia zdecydowanie wzrasta wraz ze wzrostem obszaru działalności firmy. Potwierdzają to odpowiedzi na pytania dotyczące zasięgu rynku, na którym działa przedsiębiorca. Najczęściej firmy działają na rynku lokalnym (co roku powyżej 50\% przedsiębiorców); one też mają najniższy współczynnik przeżywalności. Wyraźna jest prawidłowość: im większy rynek, tym większe szanse przeżycia kolejnego roku. Eksporterzy stanowią co roku marginalną część nowych przedsiębiorców, ale to właśnie oni częściej utrzymują się na rynku. Dane pokazują, że liczba eksporterów wśród firm nowo tworzonych nieznacznie, ale systematycznie rośnie $(2,9 \% \mathrm{w} 2002$ r., 3,7\% w rok później, 5,3\% w 2004 r.), co należy uznać za tendencję korzystną dla polskiej gospodarki. 
Badania pokazują także, że zasięg rynkowy działalności zależy ściśle od branży. Najwięcej eksporterów działa w transporcie (14,8\%) oraz obsłudze nieruchomości i firm (10\%). Sporadycznie na rynkach zagranicznych działają firmy zajmujące się edukacją, ochroną zdrowia, drobnymi usługami i - co ciekawe - pośrednictwem finansowym; odsetek takich firm działających na rynku międzynarodowym nie przekracza $1 \%$.

Oprócz sposobu działalności przedsiębiorstw na przeżywalność firm wpływają cechy właścicieli firm determinujące sukces przedsiębiorstwa: płeć, wiek, wykształcenie i doświadczenie zawodowe.

\section{Gospodarcze znaczenie MSP po wejściu Polski do Unii Europejskiej}

Małe i średnie przedsiębiorstwa, zarówno w Polsce, jak i w innych krajach Unii Europejskiej, odgrywają ogromną rolę w gospodarce. Do najczęściej stosowanych kryteriów ilościowych należy zaliczyć:

- wskaźniki dotyczące zatrudnienia w MSP,

- udział MSP w tworzeniu PKB,

- udział MSP w tworzeniu wartości dodanej,

- udział produkcji MSP w całkowitym eksporcie.

Istnieje wiele innych wielkości określających rolę MSP w gospodarce od strony jakościowej, m.in. wpływ MSP na proces restrukturyzacji i modernizacji gospodarki.

\section{Pracujący w MSP w latach 2004 i 2005}

W końcu 2004 r. liczba pracujących w przedsiębiorstwach ${ }^{11}$ ogółem wynosiła 8106,8 tys. i była praktycznie równa stanowi z końca roku poprzedniego. W 2005 r. wzrosła o 1,6\%, do 8234,1 tys. (tab. 9).

Tab. 9. Pracujący w przedsiębiorstwach według stanu na koniec lat 2004 i 2005 (z pominięciem rolnictwa i leśnictwa, rybołówstwa i rybactwa oraz administracji publicznej)

\begin{tabular}{|c|c|c|c|c|c|}
\hline \multirow[t]{3}{*}{ Rok } & \multirow[t]{2}{*}{ Ogółem } & \multicolumn{4}{|c|}{ W tym przedsiębiorstwa o liczbie zatrudnionych } \\
\hline & & 0-9 & $10-49$ & $50-249$ & powyżej 249 \\
\hline & \multicolumn{5}{|c|}{ Liczba pracujących według stanu na koniec roku (w tys.) } \\
\hline 2004 & 8106,8 & 3360,8 & 963,7 & 1461,0 & 2321,3 \\
\hline \multirow[t]{2}{*}{2005} & 8234,1 & 3380,9 & 968,4 & 1493,4 & 2391,4 \\
\hline & \multicolumn{5}{|c|}{ Rok poprzedni $=\mathbf{1 0 0}$} \\
\hline 2004 & 100,6 & 99,7 & 102,1 & 100,0 & 101,7 \\
\hline \multirow[t]{2}{*}{2005} & 101,6 & 100,6 & 100,5 & 102,2 & 103,0 \\
\hline & \multicolumn{5}{|c|}{ Liczba pracujących ogólem $=100$} \\
\hline 2004 & 100,0 & 41,5 & 11,9 & 18,0 & 28,6 \\
\hline 2005 & 100,0 & 41,1 & 11,8 & 18,1 & 29,0 \\
\hline
\end{tabular}

Źródło: Raport o stanie sektora małych i średnich przedsiębiorstw w Polsce, Polska Agencja Rozwoju Przedsiębiorczości, Warszawa 2007.

${ }^{11}$ Informacje o liczbie pracujących w przedsiębiorstwach według stanu na koniec kolejnych lat jest przedstawiana przez GUS w corocznych publikacjach pt.: Działalność przedsiębiorstw niefinansowych. 
W 2005 r. tempo wzrostu liczby pracujących było wyraźnie szybsze w firmach średnich i dużych (wzrost odpowiednio o 2,2\% i 3\%) niż w mikroprzedsiębiorstwach (do 9 zatrudnionych) i małych (o zatrudnieniu 10-49 osób) (wzrost o 0,6\% i 0,5\%).

Szerzej problem zatrudnienia w MSP w 2005 r. przedstawia ryc. 3. Jeśli przyjmiemy za 100\% liczbę pracujących w MSP według stanu na koniec 2005 r., najwięcej, bo 32,4\% osób pracowało w sekcji handel i naprawy, następnie: w przemyśle (27,1\%), obsłudze nieruchomości i firm (12,3\%), w budownictwie $(9,7 \%)$ oraz w transporcie, gospodarce magazynowej i łączności (6\%).

Ryc. 3. Struktura pracujących w MSP według stanu na koniec 2005 r. (w \%)

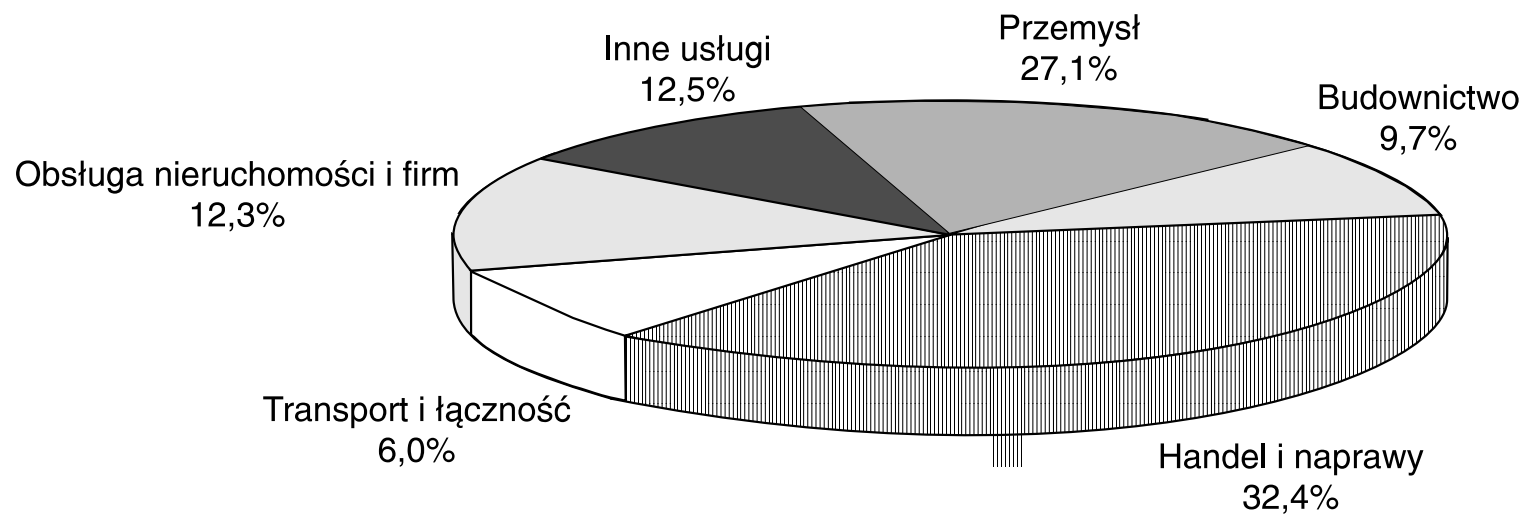

Źródło: opracowanie autorki na podstawie Raportu o stanie sektora MSP, Polska Agencja Przedsiębiorczości, Warszawa 2007.

Prezentowana wyżej struktura pracujących w MSP w ramach wyodrębnionych sekcji, z uwzględnieniem podziału na mikroprzedsiębiorstwa oraz przedsiębiorstwa małe i średnie, wykazywała duże zróżnicowanie. W grupie mikroprzedsiębiorstw poważny spadek liczby pracujących, o prawie 10\%, odnotowano w 2005 r. w przemyśle, a także o 4,4\% w transporcie, gospodarce magazynowej i łączności. Najszybszy wzrost obserwowano w pośrednictwie finansowym (o 15,8\%), w sekcji hotele i restauracje (o 7,9\%) oraz w budownictwie (o 7,6\%).

W grupie średnich przedsiębiorstw w 2005 r. najszybciej rosła liczba pracujących w pośrednictwie finansowym (o 13,8\%) oraz w sekcji hotele i restauracje (o 10,1\%).

Należy pamiętać, że duża część pracowników MSP pracowała w szarej strefie. Przeciętna liczba pracujących w szarej strefie gospodarki w 2004 r. wyniosła 405 tys., a w 2005 r. wzrosła o prawie 5\%, do 425 tys. ${ }^{12}$. W porównaniu z 2004 r. powiększyła się ona głównie w małych przedsiębiorstwach przemysłowych ( prawie o 30\%) i budowlanych, chociaż w nich stosunkowo nieznacznie (o nieco ponad 5\%). W 2005 r. pracujący w szarej strefie stanowili 14,8\% przeciętnej łącznej liczby pracujących legalnie w budownictwie, 12,2\% w sekcji handel i naprawy i 8,7\% w przetwórstwie przemysłowym ${ }^{13}$.

${ }^{12}$ Liczby ta zostały oszacowane na podstawie danych GUS publikowanych w rocznikach statystycznych. Nie należy ich interpretować w ten sposób, że np. w 2005 r. w szarej strefie pracowało 425 tys. osób fizycznych. Osoby pracujące nielegalnie zatrudniane są z reguły doraźnie lub sezonowo, dlatego liczba osób fizycznych pracujących w szarej strefie może być kilkakrotnie wyższa od przeciętnej liczby pracujących (np. zatrudnianie $1 \mathrm{mln}$ osób fizycznych średnio przez kwartał w roku oznacza przeciętną liczbę pracujących 250 tys.).

${ }^{13}$ Raport o stanie MSP, op. cit. 


\section{Udzial MSP w tworzeniu PKB}

Wartość PKB w 2004 r. wyniosła 923248 mln zł, a w 2005 r. - 980666 mln zł (tab. 11). Licząc w cenach stałych, od roku 2003 do roku 2004 wartość PKB wzrosła o 5,3\%, a od roku 2004 do roku $2005-$ o $3,5 \%$.

Tab. 10. Struktura PKB w latach 2004 i 2005

\begin{tabular}{|c|c|c|}
\hline \multirow[t]{2}{*}{ Wyszczególnienie } & 2004 & 2005 \\
\hline & \multicolumn{2}{|c|}{$\mathbf{w} \mathbf{m l n} \mathbf{z l}$} \\
\hline PKB & 923248,0 & 980666,0 \\
\hline w tym: & & \\
\hline Cła i podatki pośrednie minus dotacje & 102873,0 & 116982,0 \\
\hline Wartość dodana brutto ogółem & 820375,0 & 863684,0 \\
\hline w tym: wartość dodana brutto (bez sekcji A i B) & 778435,0 & 823595,0 \\
\hline $\mathrm{w}$ tym przedsiębiorstwa & 646232,6 & 683053,4 \\
\hline $\begin{array}{l}\text { w tym liczba zatrudnionych w przedsiębiorstwach } \\
\text { zatrudniających: } 0-9 \text { osób }\end{array}$ & 285655,0 & 301427,2 \\
\hline 10-49 osób & 68806,6 & 73572,3 \\
\hline 50-249 osób & 91462,8 & 93154,7 \\
\hline \multirow[t]{2}{*}{ powyżej 249 osób } & 200308,2 & 214899,2 \\
\hline & \multicolumn{2}{|c|}{ PKB $=100$} \\
\hline PKB & 100,0 & 100,0 \\
\hline $\begin{array}{l}\text { w tym: } \\
\text { Cla i podatki pośrednie minus dotacje }\end{array}$ & 11,1 & 11,9 \\
\hline Wartość dodana brutto & 88,9 & 88,1 \\
\hline w tym: wartość dodana brutto (bez sekcji A i B) & 84,3 & 84,0 \\
\hline w tym przedsiębiorstwa & 70,0 & 69,6 \\
\hline $\begin{array}{l}\text { w tym liczba zatrudnionych w przedsiębiorstwach } \\
\text { zatrudniających: 0-9 osób }\end{array}$ & 30,9 & 30,7 \\
\hline 10-49 osób & 7,5 & 7,5 \\
\hline 50-249 osób & 9,9 & 9,5 \\
\hline powyżej 249 osób & 21,7 & 21,9 \\
\hline Udział MSP w tworzeniu PKB & 48,3 & 47,7 \\
\hline Udział MSP w tworzeniu wartości dodanej brutto ogółem & 54,4 & 54,2 \\
\hline
\end{tabular}

Źródło: Raport o MSP, Polska Agencja Przedsiębiorczości, Warszawa 2007.

Udział MSP w tworzeniu produktu krajowego brutto ${ }^{14}$ w 2004 r. wyniósł 48,3\%, w tym mikroprzedsiębiorstw - 30,9\%, małych przedsiębiorstw - 7,5\%, a średnich - 9,9\%. Te wielkości

${ }^{14}$ Ujmując ogólnie, PKB jest sumą wartości dodanej brutto oraz kwoty podatków pośrednich (w tym VAT) i ceł, które wpłynęły do budżetu w danym roku, pomniejszoną o wielkość dotacji. Kwoty podatków i ceł, których udział w PKB w 2005 r. wyniósł 11,9\%, nie dzieli się między sekcje gospodarki ani między przedsiębiorstwa różnej wielkości (nie ma technicznej możliwości przeprowadzenia takich szacunków). Dlatego jako udział MSP w PKB przyjmuje się relację wartości dodanej brutto wytworzonej 
uwzględniają wartość dodaną wytworzoną przez pracujących i MSP działające w tzw. szarej strefie gospodarczej. Analogiczny wskaźnik udziału MSP dla 2003 r. miał wartość 48\% (mikroprzedsiębiorstwa - 32\%, małe firmy - 7,5\%, średnie firmy - 8,5\%). W latach 2003 i 2004 nie odnotowano więc istotnej zmiany udziału MSP w tworzeniu PKB. Żadne poważniejsze zmiany nie wystąpiły również w 2005 r. (ryc. 4).

Ryc. 4. Struktura PKB w 2005 r.

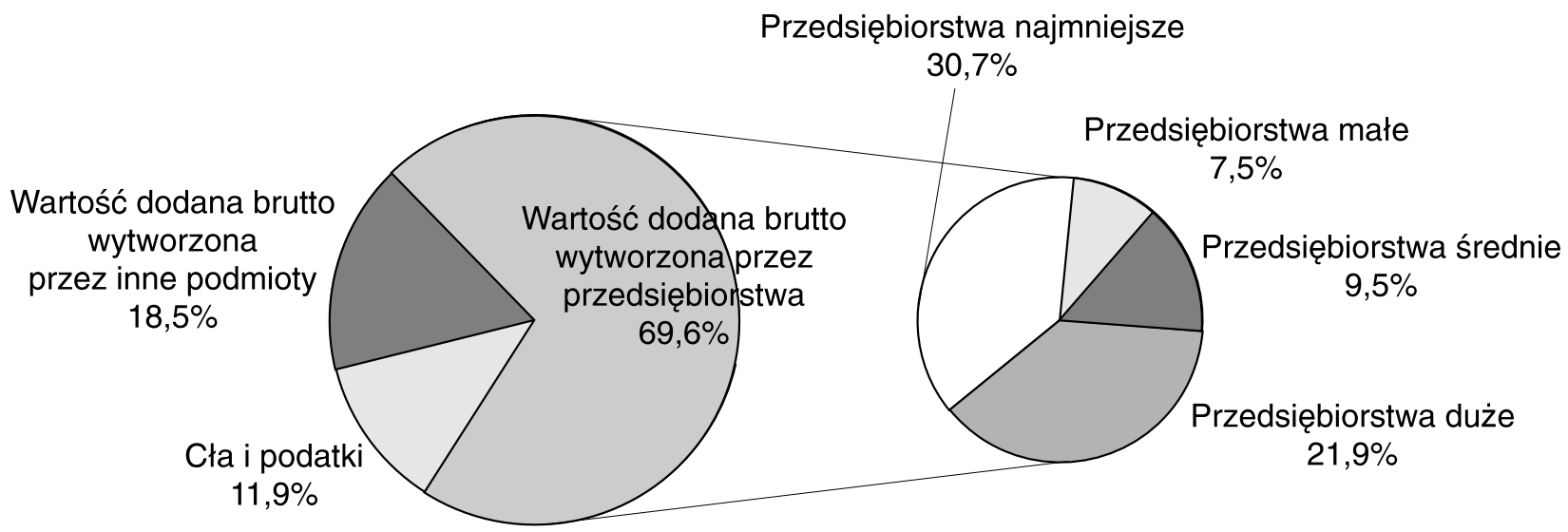

Źródło: opracowanie autorki na podstawie Raportu o stanie sektora MSP, Polska Agencja Przedsiębiorczości, Warszawa 2007.

Jeszcze bardziej stabilny był w latach 2003-2005 udział MSP w tworzeniu wartości dodanej brutto ogółem ${ }^{15}$. Wyniósł on w kolejnych latach odpowiednio: 54,3\%, 54,4\% i 54,2\%. Zmienił się natomiast udział poszczególnych kategorii MSP w tworzeniu wartości dodanej brutto. Udział mikroprzedsiębiorstw spadł o 1,3 punktu procentowego, z 36,2\% do 34,9\%, lecz niemal o tyle samo punktów wzrósł udział przedsiębiorstw średnich - z 9,6\% do 10,8\%. Wzrósł także udział dużych firm - z 24,1\% do 24,9\%.

\section{Przychody przedsiębiorstw różnej wielkości z całoksztaltu działalności}

W 2005 r. przychody przedsiębiorstw ogółem z całokształtu działalności ${ }^{16}$ (bez rolnictwa i leśnictwa, rybołówstwa i rybactwa oraz administracji publicznej) wyniosły $2257202 \mathrm{mln}$ zł i były wyższe o 3,2\% niż rok wcześniej (tab. 11). Tak wysoki wzrost był skutkiem m.in. szybkiego wzrostu sprzedaży w sekcjach: przetwórstwo przemysłowe (o 21,1\%), hotele i restauracje (o 21,2\%) oraz transport, gospodarka magazynowa i łączność (o 15,6\%).

przez MSP do ogólnej wartości PKB. W 2005 r. mikroprzedsiębiorstwa oraz przedsiębiorstwa małe, średnie i duże wytworzyły ogółem 73,9\% PKB. Łącznie z 11,9-procentowym udziałem podatków i ceł jest to $85,8 \%$ PKB. Pozostałe 14,2\% PKB wytworzyły przedsiębiorstwa zajmujące się rolnictwem, leśnictwem, rybołówstwem i rybactwem oraz indywidualne gospodarstwa rolne (czyli sekcje A i B), a także: jednostki i zakłady budżetowe, gospodarstwa pomocnicze zakładów budżetowych oraz organizacje społeczne, polityczne i wyznaniowe.

${ }^{15}$ Wartość dodana brutto ogółem wyniosła w 2005 r. 863684 mln zł; za: Raport o stanie sektora MSP, Polska Agencja Przedsiębiorczości, Warszawa 2007.

${ }^{16}$ Informacja o wielkości przychodów jest przedstawiana przez GUS w corocznych publikacjach pt.:

Działalność przedsiębiorstw niefinansowych. 
Tab. 11. Przychody przedsiębiorstw z całokształtu działalności w latach 2004 i 2005 (z pominięciem rolnictwa i leśnictwa, rybołówstwa i rybactwa oraz administracji publicznej)

\begin{tabular}{|c|c|c|c|c|c|}
\hline \multirow[t]{3}{*}{ Rok } & \multirow[t]{2}{*}{ Ogółem } & \multicolumn{4}{|c|}{ W tym przedsiębiorstwa o liczbie zatrudnionych } \\
\hline & & 0-9 & $10-49$ & $50-249$ & powyżej 249 \\
\hline & \multicolumn{5}{|c|}{ Przychody (w mln zl) } \\
\hline 2004 & 2186647 & 540195 & 323941 & 487104 & 835407 \\
\hline \multirow[t]{2}{*}{2005} & 2257202 & 551679 & 322171 & 501310 & 882042 \\
\hline & \multicolumn{5}{|c|}{ Rok poprzedni $=100$} \\
\hline 2004 & 112,6 & 109,1 & 108,1 & 116,0 & 115,0 \\
\hline \multirow[t]{2}{*}{2005} & 103,2 & 102,1 & 99,5 & 102,9 & 105,6 \\
\hline & \multicolumn{5}{|c|}{ Przychody ogólem $=100$} \\
\hline 2004 & 100,0 & 24,7 & 14,8 & 22,3 & 38,2 \\
\hline 2005 & 100,0 & 24,4 & 14,3 & 22,2 & 39,1 \\
\hline
\end{tabular}

W 2004 r. tempo wzrostu przychodów jedynie w firmach średnich (wzrost o 16\%) było wyższe niż w dużych przedsiębiorstwach (wzrost o 15\%). W rok później pod względem dynamiki przychodów żadna grupa MSP nie dorównywała już dużym przedsiębiorstwom (w grupie firm zatrudniających 10-49 osób przychody w 2005 r. nawet nieznacznie się zmniejszyły).

Problem kształtowania się struktury przychodów MSP w 2005 r. przybliża ryc. 5.

Ryc. 5. Struktura przychodów MSP w 2005 r. (w \%)

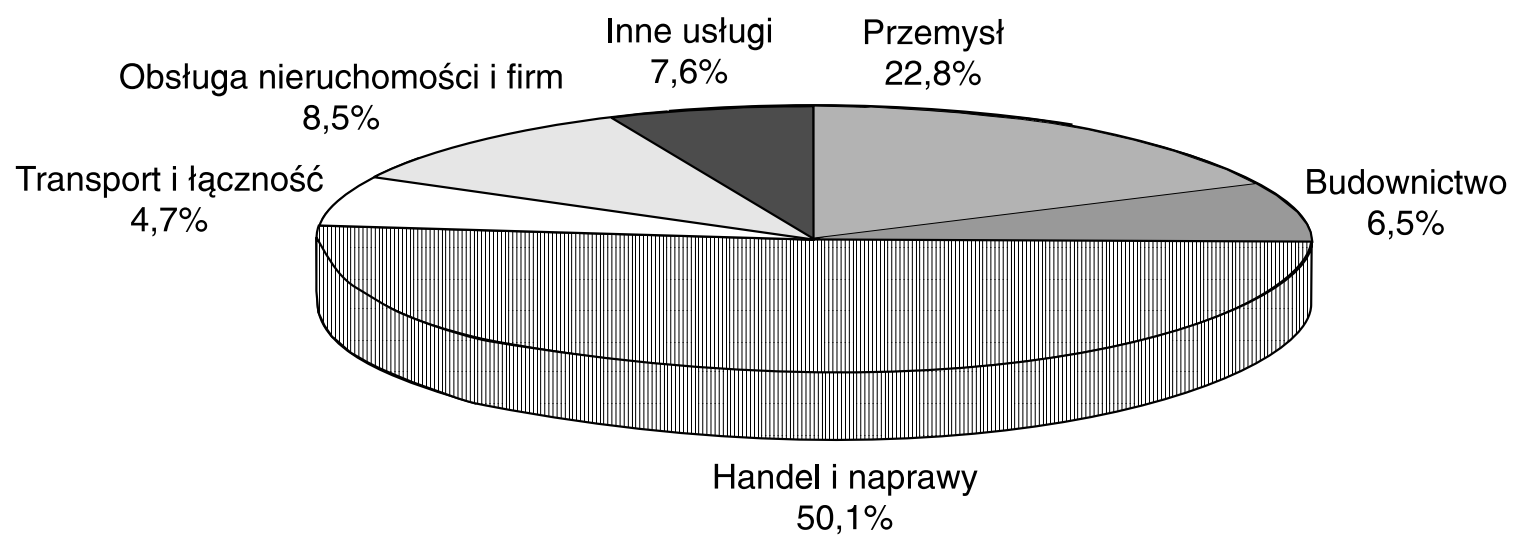

Źródło: Raport o stanie małych i średnich przedsiębiorstw, Polska Agencja Przedsiębiorczości, Warszawa 2007.

Najwyższy udział w całości przychodów MSP w 2005 r. wykazywały sekcje: handel i naprawy, przemysł, obsługa nieruchomości i firm.

Podsumowując rozważania na temat znaczenia MSP w polskiej gospodarce, należy stwierdzić, że podobnie jak w innych krajach Unii Europejskiej, ich rola jest bardzo duża. Stanowią one lokomotywę przedsiębiorczości. Świadczą o tym z jednej strony cechy sektora MSP: duża elastyczność w dostosowywaniu się do zmieniającego się popytu na rynku, silna motywacja przedsiębiorców wynikająca ze ścisłego związku między rentownością firmy a dochodami właściciela, ograniczona biurokracja, niska kapitałochłonność, wpływ na lokalną przedsiębiorczość, duża zdolność do kreowania nowych miejsc pracy i wiele innych, z drugiej zaś: konkretne ilościowe wskaźniki dotyczące ilości MSP i ich udziału w ogólnej liczbie przedsiębiorstw w Polsce, udziału MSP w zatrudnieniu, wielkości PKB, wartości dodanej w ogólnych przychodach przedsiębiorstw itp. 
Liczba aktywnych MSP w 2004 r. przekroczyła 1690 tys. i stanowiła 99,8\% wszystkich przedsiębiorstw, a liczba zatrudnionych w MSP w 2005 r. wyniosła 8234,1 tys., czyli ponad 71\% ogółu pracowników zatrudnionych we wszystkich przedsiębiorstwach. Ponadto w 2005 r. sektor MSP wytworzył 47,7\% PKB i 54,2\% ogólnej wartości dodanej brutto. Należy podkreślić, że znaczenie mikroprzedsiębiorstw oraz przedsiębiorstw małych i średnich było zróżnicowane w poszczególnych sekcjach gospodarki. Niepokój w zakresie rozwoju sektora MSP w Polsce budzi kilka kwestii:

- stosunkowo niski i zmniejszający się odsetek przedsiębiorstw aktywnych w ogólnej liczbie zarejestrowanych. W 1999 r. wynosił on ponad 64\%, a w 2004 r. niewiele ponad 50\%;

- krótka przeżywalność przedsiębiorstw utworzonych w latach 2001-2004. Badania wykazuja, że najtrudniej przedsiębiorstwu przetrwać pierwszy rok działalności; właśnie w tym okresie działalność kończyło około 40\% przedsiębiorstw (z niewielkimi różnicami w poszczególnych sekcjach gospodarki);

- niska skłonność innowacyjna polskich przedsiębiorców. Według badań Polskiej Agencji Przedsiębiorczości tylko 5\% małych firm (13\% większych) prowadzi działalność badawczo-rozwojową i zdecydowana większość nie wydaje na ten cel więcej niż 20 tys. zł rocznie;

- duża część pracowników MSP pracuje w szarej strefie. Przeciętna liczba pracujących w szarej strefie gospodarki wyniosła w 2004 r. 405 tys., a w 2005 r. wzrosła o prawie 5\% - do 425 tys. W 2005 r. ogólny udział pracowników MSP pracujących w szarej strefie wyniósł blisko 9\%, a w budownictwie - aż 14,8\%, w handlu 12,2\%;

- zmniejszanie się w latach 2004 i 2005 udziału MSP w ogólnych przychodach przedsiębiorstw, ze względu na gorsze wyniki małych firm.

Przytoczone - jedynie niektóre - niepokojące fakty dotyczące funkcjonowania sektora MSP wskazują na konieczność wsparcia tego sektora przez państwo i samorządy terytorialne w ramach obowiązujących reguł wspólnej polityki Unii Europejskiej wobec MSP i wiążącej się z nią wspólnej polityki Unii Europejskiej w zakresie konkurencji ${ }^{17}$. Chodzi o usuwanie barier w zakresie rozwoju tego sektora: zmniejszenie pozapłacowych kosztów pracy, m.in. przez obniżenie składki rentowej po stronie pracodawców; obniżenie podatków PIT i CIT; ograniczenie liczby koncesji i zezwoleń; przywrócenie dialogu z przedsiębiorcami; przyspieszenie uchwalania planów zagospodarowania przestrzennego, przygotowanie nowej ustawy o partnerstwie publiczno-prywatnym; dokończenie prywatyzacji.

\section{Literatura}

1. Bartkowiak P., Małe i średnie przedsiębiorstwa w Unii Europejskiej: teoria i praktyka, Wydawnictwo Państwowej Wyższej Szkoły Zawodowej w Kaliszu, Kalisz 2005.

2. Decyzja Rady WE 21/57 z października 2001 r. dotycząca nowej spółki akcyjnej, określanej mianem spółki europejskiej.

3. Dominiak P., Sektor MSP we wspótczesnej gospodarce, PWN, Warszawa 2005.

4. Kwiatkowska W., Rola małych i średnich przedsiębiorstw na rynku pracy w gospodarce polskiej, „Gospodarka w praktyce i teorii”, 2/19/2006.

5. Małe i średnie przedsiębiorstwa w Polsce a integracja europejska, M. Bednarczyk (red.), AE, Kraków 2004.

${ }^{17}$ Pomoc publiczna w Unii Europejskiej uregulowana jest generalnie Traktatem o Wspólnotach Europejskich (art. 92-94) oraz przepisami wykonawczymi do TWE (decyzje Komisji Europejskiej, dyrektywy, komunikaty i listy). 
6. Pomoc publiczna dla matych i średnich przedsiębiorstw. Mity i rzeczywistość, F. Misiąg (red.), PWE, Warszawa 2005.

7. Przede wszystkim MSP. Europa jest dobra dla MSP a MSP sq dobre dla Europy, Komisja Europejska DG ds. Przedsiębiorstw i Przemysłu, 2006.

8. Raport o stanie sektora małych i średnich przedsiębiorstw w Polsce, Polska Agencja Przedsiębiorczości, Warszawa 2007.

9. Słojewska A., Polska spóźnia się z reformami, „Rzeczpospolita”, nr 68, 21.03.2006 r. .

10. Stan sektora MSP w 2003 r. Tendencje rozwojowe w latach 1994-2005, J. Chmiel (red.), MGiP PARP, Warszawa 2005.

11. Warunki powstania i działania oraz perspektywy rozwojowe polskich przedsiębiorstw powstałych w latach 2001-2006, GUS, Warszawa 2007.

12. Załącznik do Rozporządzenia Komisji Europejskiej nr 346/2004 zmieniającego i rozszerzającego zakres Rozporządzenia Komisji Europejskiej nr 70/2001.

13. Żołnierski A., Innowacyjność 2006, Polska Agencja Rozwoju Przedsiębiorczości, Warszawa 2006.

\section{Significance of Small and Middle Enterprises in Poland since 2000}

Small and middle enterprises (SME) are the basic part of the economy in European Union including Poland. Typical feature of them are: high level of flexibility in adaptation to the changes in business environment, strong motivation of entrepreneurs because of the relation between profitability of an enterprise and income of its owner, high efficiency of prospering of SME that corresponds to the big financial discipline that dominates in SME sector and low absorption of capital in the production areas.

All these characteristics cause SME sector plays very important role in increasing Gross Domestic Product and added value as well as in increasing the employment. In 2004 the number of active enterprises of this sector in Poland was estimated to over 1690000 which was the $99,8 \%$ of all enterprises in this country. The number of employees in Polish SME sector in 2005 was about 8234,1 that was over $71 \%$ of total number of employees working in all the enterprises. Moreover, in 2005 the SME sector generated 47,7\% of gross domestic product and $54,2 \%$ of added value. It should be emphasized that importance of micro, middle and small enterprises was different in particular sectors of economy like: industrial processing, trade, constructions, hotels and restaurants, transport etc.

Unfortunately, some problems occurred in development of SME sector, for example: the decreasing number of active enterprises in total number of registered enterprises, low innovativeness of Polish middle and small enterprises, short time of life, high rate of employment in "the grey zone". It shows the importance of supporting this sector by national or local government under the auspices of EU which formulated the rules of common politics for SME sector. You can find these regulations in common European SME Policy and European Competition Policy. It is necessary to remove all barriers to the SME sector progress by reducing off-pay costs, decreasing taxes, limiting number of concessions and certificates of approval. 